\title{
ANALISIS DAN RANCANGAN MANAJEMEN PROSES BISNIS UNTUK LAYANAN PELANGGAN DI PT. PGAS TELEKOMUNIKASI NUSANTARA
}

\author{
Kemas Hasyim Azhari ${ }^{1}$, Thomas Budiman ${ }^{2}$, \\ Rachmawaty Haroen ${ }^{3}$, Verdi Yasin ${ }^{4}$ \\ Program Studi Sistem Informasi, Fakultas Ilmu Komputer ${ }^{1}$ \\ Program Studi Teknik Informatika, Fakultas Ilmu Komputer ${ }^{2}$ \\ Program Studi Sistem Informasi, Fakultas Ilmu Komputer ${ }^{3}$ \\ Program Studi Teknik Informatika, Fakultas Ilmu Komputer ${ }^{4}$ \\ Sekolah Tinggi Manajemen Informatika dan Komputer Jayakarta, Jakarta \\ kmszhr2@gmail.com, thomas@stmik.jayakarta.ac.id, \\ rahmawatyharoen@gmail.com, verdiyasin29@gmail.com
}

Received: February 08, 2021. Revised: March 10, 2021. Accepted: April 25, 2021. Published: June 20, 2021. Issue Period: Vol.5 No.1 (2021), Pp.48-68

\begin{abstract}
Abstrak: Manajemen Proses Bisnis untuk layanan pelanggan perusahaan merupakan rangkaian kegiatan menyeluruh untuk mendefinisikan jenis produk dan layanan yang akan menjadi kebutuhan utama pelanggan, sehingga kualitas hasil layanan dapat terencana dan terukur. Perancangan proses bisnis adalah sebuah kerangka dari proses inti yang berkembang dari sebuah strategi bisnis jangka pendek dan jangka panjang, sehingga strategi bisnis tersebut akan menentukan pilar-pilar bisnis yang akan dijalankan. Melayani kebutuhan pelanggan dan pihak yang berkepentingan akan menjadi fokus utama sebuah proses bisnis yang akan dilakukan di dalam organisasi. Penerapan manajemen proses bisnis merupakan salah satu metode untuk mengidentifikasi dan mengevaluasi bisnis suatu perusahaan dan untuk mengetahui kondisi terkini perusahaan dalam menyusun program improvement yang dapat dilakukan melalui proses deskriptif. Output dan penerapan manajemen proses bisnis ini berupa peningkatan efisiensi dan produktivitas perusahaan dalam aspek biaya dan waktu serta peningkatan kualitas produk dan jasa yang dihasilkan, sekaligus melakukan mitigasi risiko bisnis yang dapat terjadi. Metode pengumpulan data, metode analisis, metode pengembangan, metode desain perancangan dan metode pengujian adalah metode penelitian yang digunakan secara sistematis sehingga mencakup beberapa kegiatan perbaikan bertahap proses kerja dari kondisi sebelumnya dan peningkatan kehandalan system untuk memperoleh fakta-fakta atau prinsip-prinsip dari pengetahuan dengan cara issue register dan melakukan root cause analysis dengan beberapa penilaian dampak dengan menganalisa secara kuantitatif, heuristic design, simulasi, flow analysis, pareto analysis dan pick chart, queue, hingga rancang ulang proses yang dilakukan secara sistematis.
\end{abstract}

Kata kunci: strategi bisnis, pilar bisnis, peningkatan efisiensi dan produktivitas, mitigasi risiko bisnis, root cause analysis

Abstract: Business Process Management for corporate customer service is a comprehensive series of activities to define the types of products and services that will be the main needs of customers, so that the quality of service results can be planned and measured. Business process design is a framework for a core process that develops from a short-term and longterm business strategy, so that the business strategy will determine the pillars of the business that will be carried out. Serving the needs of customers and interested parties will be the main

DOI: $10.52362 /$ jisicom.v5i1.381

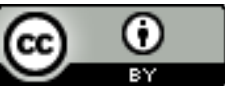

Ciptaan disebarluaskan di bawah Lisensi Creative Commons Atribusi 4.0 Internasional. 
Journal of Information System, Informatics and Computing

Website/URL: http://journal.stmikjayakarta.ac.id/index.php/jisicom

Email: jisicom@stmikjayakarta.ac.id , jisicom2017@gmail.com

focus of a business process that will be carried out within the organization. The application of business process management is a method for identifying and evaluating a company's business and for finding out the current condition of the company in developing improvement programs that can be done through a descriptive process. The output and application of business process management are in the form of increasing the efficiency and productivity of the company in terms of cost and time as well as improving the quality of products and services produced, as well as mitigating business risks that may occur. Data collection methods, analysis methods, development methods, design design methods and testing methods are research methods that are used systematically so that it includes several activities for gradual improvement of the work process from previous conditions and increasing system reliability to obtain facts or principles from knowledge with how to issue register and perform root cause analysis with several impact assessments by quantitative analysis, heuristic design, simulation, flow analysis, pareto analysis and pick chart, queue, up to a systematic redesign to the process.

Keywords: business strategy, business pillars, increasing efficiency and productivity, mitigating business risk, root cause analysis

\section{PENDAHULUAN}

Dengan meningkatnya persaingan bisnis antar perusahaan, setiap perusahaan dituntut untuk semakin berkembang. Pengembangan dan perbaikan yang berkelanjutan yang dilakukan adalah merupakan peningkatan produktivitas dan kualitas proses bisnis, serta pengurangan biaya pengerjaan bisnis. Hal-hal tersebut dapat dilakukan dengan baik apabila perusahaan mampu melakukan evaluasi proses yang berjalan secara keseluruhan dengan cepat. Proses yang komplek, pekerjaan yang tidak terdata, serta kesulitan dalam memantau proses di setiap departemen menjadi tantangan tersendiri bagi perusahaan untuk mengevaluasi proses secara keseluruhan. Manajemen Proses Bisnis adalah solusi dalam menghadapi tantangan tersebut.

Teknologi informasi sekarang ini sudah semakin berkembang, kebutuhan akan sebuah informasi yang berkualitas sangatlah diperlukan. Implementasi Teknologi Informasi harus benar-benar selaras dengan tujuan bisnis dan secara berkesinambungan membantu organisasi mencapai tujuan tersebut. Kunci penghubung antara bisnis dan teknologi informasi adalah BPM.

Efisiensi dan produktivitas dari sebuah kegiatan usaha menjadi sangat penting dalam pertarungan bisnis. Penerapan Manajemen Proses Bisnis merupakan salah satu metode untuk mengidentifikasi dan mengevaluasi proses bisnis suatu perusahaan untuk mengetahui kondisi sebenarnya dan menyusun program perbaikan yang dapat dilakukan berupa peningkatan efisiensi dan produktivitas perusahaan dalam aspek biaya dan waktu serta peningkatan kualitas produk dan jasa yang dihasilkan.

DOI: $10.52362 /$ jisicom.v5i1.381

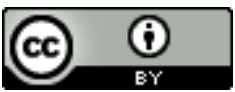

Ciptaan disebarluaskan di bawah Lisensi Creative Commons Atribusi 4.0 Internasional. 
Journal of Information System, Informatics and Computing

Website/URL: http://journal.stmikjayakarta.ac.id/index.php/jisicom

Email: jisicom@stmikjayakarta.ac.id , jisicom2017@gmail.com

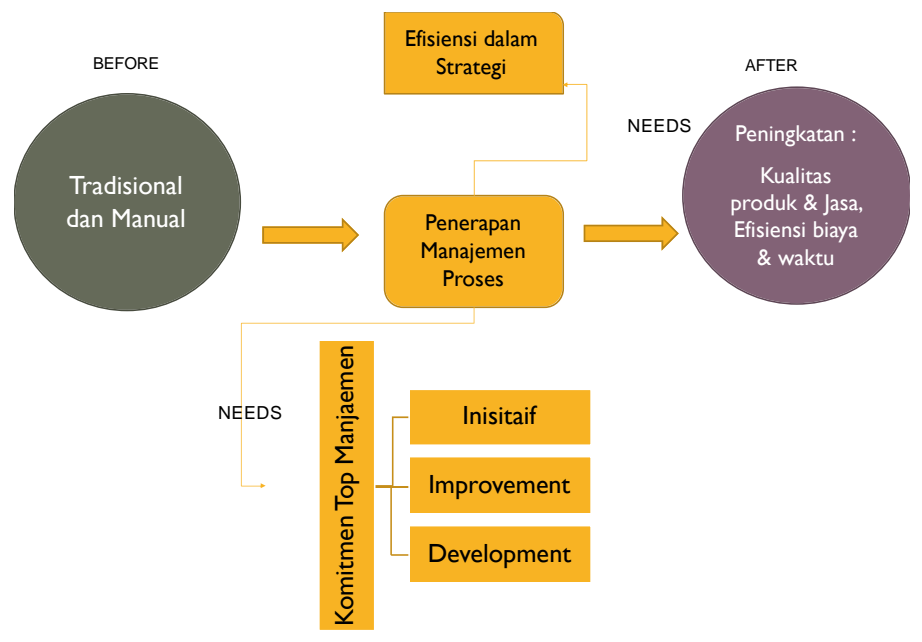

Proses bisnis merupakan sekumpulan aktivitas yang dilakukan oleh sumber daya yang mengubah input menjadi output. Efektivitas operasional berarti melakukan aktivitas yang mirip dengan lebih baik daripada pesaing. Posisi strategis menurut Porter (n.d) dalam Diawati, (2017) adalah melakukan aktivitas yang berbeda dari kompetitor atau melakukan aktivitas yang sama dengan cara yang berbeda. Efektivitas operasional terkait dengan mencapai keunggulan pada aktivitas atau fungsi individu, strategi terkait dengan kombinasi aktivitas.

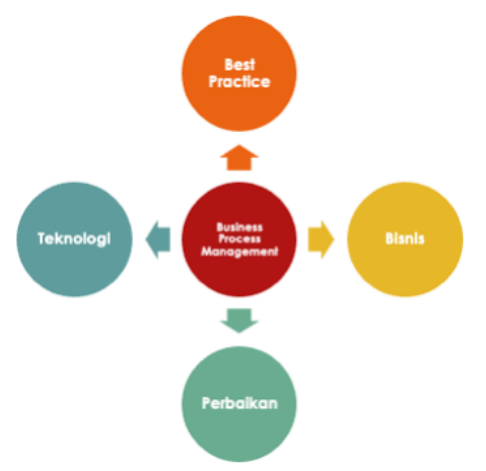

Manajemen Proses Bisnis adalah sebuah pendekatan sistematik untuk membuat organisasi lebih efektif, lebih efisien dan lebih mampu adaptasi terhadap perubahan lingkungan. Salah satu kegunaan Manajemen Proses Bisnis adalah untuk perbaikan dan pengembangan. Langkah untuk melakukan sebuah tema perbaikan adalah identifikasi pemetaan proses bisnis yang mempunyai bottleneck atau masalah di dalam organisasi , seperti :

- Terhambatnya proses terhadap objective process (ineffectivity).

- Proses boros dan tidak memberikan value (Defficiency).

- Minimnya proses pengendalian, sehingga objective proses tidak tercapai (uncontrolled).

- Proses yang berulang dan saling tumpang tindih, padahal objective prosesnya sama (overlaping).

- Proses yang saling terpisah satu sama lain dalam mencapai suatu objective (unintegrated).

- Bahkan masalah terkait dengan strategi proses bisnis yang tidak terukur (strategical failure).

Melakukan perancangan ulang proses sebagai tahapan implementasi yang berkelanjutan dapat di terapkan secara bertahap di organisasi. Pengukuran output dan input dari suatu proses yang SMART (Specific, Measureable, Align, Realistic, Timelines) yang tepat akan menilai kepuasan pelanggan. Continuous

DOI: $10.52362 /$ jisicom.v5i1.381

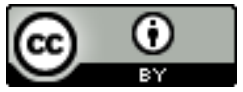

Ciptaan disebarluaskan di bawah Lisensi Creative Commons Atribusi 4.0 Internasional. 
Journal of Information System, Informatics and Computing

Website/URL: http://journal.stmikjayakarta.ac.id/index.php/jisicom

Email: jisicom@stmikjayakarta.ac.id , jisicom2017@gmail.com

Improvement akan membantu fungsi Audit Internal untuk melakukan rekomendasi perbaikan dan tindak lanjut pengembangan yang berkelanjutan serta mitigasi risiko bisnis yang diperlukan.

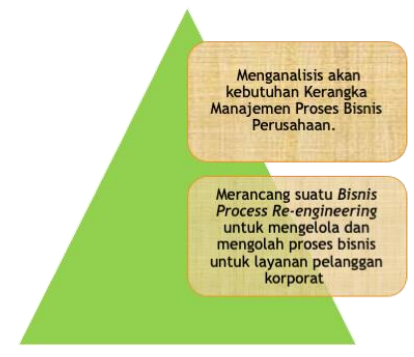

\section{METODE DAN MATERI}

(Wibowo, 2014) menjelaskan persaingan dalam mengelola sebuah bisnis baik yang memiliki skala kecil, menengah dan besar sangatlah ketat. Bisnis yang tidak dapat bersaing, otomatis akan tersingkir. Dalam iklim kompetisi yang ketat tersebut, kunci sukses bisnis adalah bagaimana kita memuaskan pelanggan dan mendapatkan lebih banyak pelanggan baru. Tuntutan pelanggan atas produk/jasa yang mereka beli semakin tinggi. Pelanggan menginginkan produk dengan harga yang murah, kualitas baik dan waktu pelayanan yang cepat. Pada masa lalu, pelanggan cukup dapat terpuaskan bila mereka dapat memperoleh produk/jasa dengan harga murah atau kualitas produk yang baik atau pengiriman yang tepat waktu. Namun saat ini ketiga hal tersebut mutlak menjadi tuntutan yang harus dipenuhi ketiganya dan bukan hanya salah satunya. Perlunya mempertahankan mutu produk, layanan dan pemasaran yang semakin meningkat tajam. Diperlukan inovasi yang diperlukan untuk menjadi pilihan sebagai salah satu strategi yang dapat merebut pasar dan sekaligus pelanggan.

Definisi Dumas, La Rosa, dkk., (2013): "BPM adalah seni dan ilmu pengetahuan untuk mengawasi bagaimana pekerjaan dilakukan dalam sebuah organisasi untuk memastikan hasil yang konsisten dan untuk memanfaatkan kesempatan perbaikan". Rosing dkk. menganggap definisi ini hanya menyebutkan pekerjaan dan hasil sehingga menekankan pada perbaikan pada satu unit pekerjaan dalam sebuah proses dan tidak pada proses secara keseluruhan.

Definisi harmon (2007) istilah BPM mengacu pada pendekatan yang lebih sintesis dan komprehensif untuk perubahan proses yang menggabungkan manajemen, rancang ulang, peningkatan dan otomasi proses. Rosing dkk menyebut bahwa definisi ini cukup baik dan ringkas, namun tidak menjelaskan apakah BPM adalah pengelolaan tugas dalam satu proses (mis., otomasi) atau cara bagaimana proses dapat berulang, dimodifikasi, dan diperbaiki dari waktu ke waktu. Mereka menganggap beberapa kata diperlukan untuk memperjelas bahwa BPM adalah yang terakhir dan juga menekan kebutuhan untuk memelihara proses sebagai bagian dari kelangsungan usaha perusahaan. Proses mencakup batasan organisasi, menghubungkan orang, arus informasi, sistem dan aset lainnya, untuk menciptakan dan memberikan nilai bagi pelanggan dan konstituen". Definisi ini dianggap terlalu panjang, namun tidak merangkum secara menyeluruh gagasan penata layanan atau kontrol proses dalam keadaan mapan.

Inovasi merupakan pemikiran kreatif dan implementatif, perubahan yang diinginkan dalam inovasi terdiri dari empat dimensi yaitu : inovasi produk, inovasi proses, inovasi posisi dan inovasi paradigma. (Tidd \& Beasant, 2014) dalam (Diawati, 2017).

Definisi sederhana dari proses adalah satu set aktivitas dan sumber daya yang terdefinisi dan menerima input serta mengubahnya menjadi output. ruang lingkup proses meluas mulai dari yang paling besar dan kompleks sampai kepada yang paling mendasar. Semua aktivitas pekerjaan adalah sebuah proses. Penerapan manajemen proses bisnis merupakan salah satu metode untuk mengidentifikasi dan mengevaluasi proses bisnis suatu perusahaan untuk mengetahui kondisi aktual perusahaan dan menyusun

DOI: $10.52362 /$ jisicom.v5i1.381

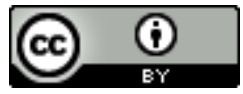

Ciptaan disebarluaskan di bawah Lisensi Creative Commons Atribusi 4.0 Internasional. 
program improvement yang dapat dilakukan. Output dari penerapan manajemen proses bisnis ini berupa peningkatan efisiensi perusahaan dalam aspek biaya dan waktu serta peningkatan kualitas produk dan jasa yang dihasilkan.

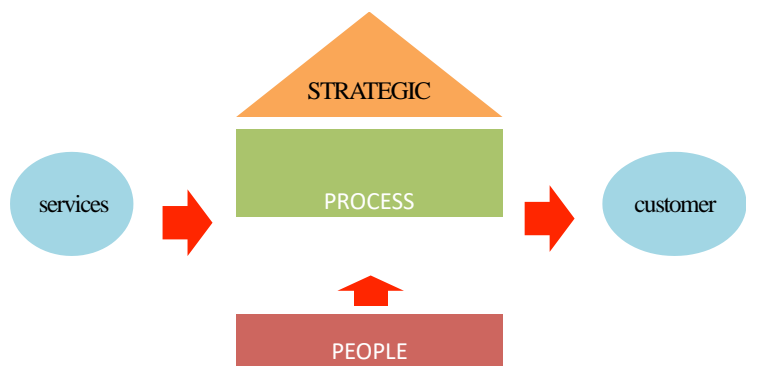

Penerapan manajemen proses bisnis yang penulis lakukan adalah merupakan Inisiatif dan Improvement di Korporasi. Dibutuhkan suatu pemikiran panjang dan terarah, bagaimana mengatur dan mengawal keseluruhan rangkaian aktivitas/kegiatan bisnis perusahaan dengan tujuan memenuhi keinginan pelanggan dengan target waktu yang disepakati dan dengan harga yang ditentukan serta menjamin mutu layanan yang handal. Observasi yang penulis lakukan bahwa ada beberapa yang memiliki kesamaan dengan tema penelitian di lakukan yaitu sama-sama meneliti tentang proses bisnis. Namun objek dan tempat yang diteliti menjadi perbedaan fokus yang di implementasi. Penelitian yang akan penulis lakukan lebih fokus ke proses bisnis untuk layanan pelanggan dan tempatnya juga berbeda dengan penelitian lainnya. Meskipun telah disebutkan adanya penelitian dengan tema yang serupa dengan penelitian yang dilakukan, namun mengingat subjek, objek dan tempat penelitian yang berbeda, maka penulis semakin tertarik untuk melakukan penelitian tentang Analisis dan Rancangan Manajemen Proses Bisnis Untuk Layanan Pelanggan Korporat di PT. PGAS Telekomunikasi Nusantara.

Metode Penelitian adalah kegiatan untuk memperoleh fakta-fakta atau prinsip-prinsip dari pengetahuan dengan cara mengumpulkan, mencatat, dan menganalisa data yang dikerjakan secara sistematis.

"A rule of thumb is that a lousy process
will consume ten times as many hours as
the work itself requires. A good process
will eliminate the wasted time, and
technology will speed up the remaining
real work."
Bill Gates, "Business @ The
Speed Of Though

\subsection{Metode Pengumpulan Data}

Untuk memperoleh data primer dilakukan pengamatan dengan metode pengamatan langsung mengenai objek yang diteliti agar diperoleh gambaran yang jelas tentang objek tersebut, selanjutnya tahap wawancara dan diskusi/forum grup discussion dilakukan dengan tanya jawab secara langsung dengan pemilik proses sesuai dengan subjek penelitian dan sesuai data yang dibutuhkan, dan terakhir adalah mengupas daftar Pustaka berupa buku-buku, jurnal maupun situs internet serta forum diskusi internet ataupun referensi lain mengenai informasi yang dibutuhkan dan berhubungan dengan materi penulisan skripsi.

\subsection{Metode Analisis}

DOI: $10.52362 /$ jisicom.v5i1.381

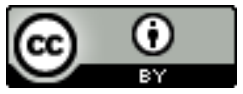

Ciptaan disebarluaskan di bawah Lisensi Creative Commons Atribusi 4.0 Internasional. 
Journal of Information System, Informatics and Computing

Website/URL: http://journal.stmikjayakarta.ac.id/index.php/iisicom

Email: jisicom@stmikjayakarta.ac.id , jisicom2017@gmail.com

Penelitian menggunakan teknik deskripstif dalam bentuk naratif yaitu hasil data pengamatan, wawancara, dan dokumentasi sehingga memberikan komponen pada penelitian yaitu reduksi data, penyajian data, penarikan kesimpulan dan verifikasi.

\subsection{Kerangka Pemikiran}

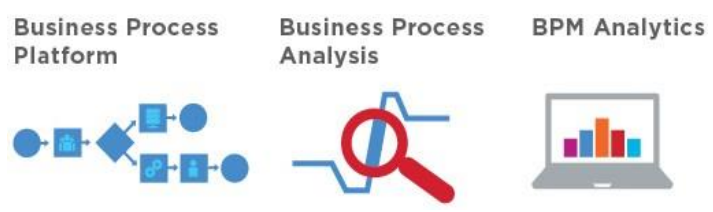

\subsection{Paradigma}

Salah satu bagian penting dalam proses bisnis adalah kontinuitas dari seluruh aktivitas pengelolaan proses atau yang dikenal dengan siklus hidup BPM. Motivasi dibalik studi terkait siklus hidup BPM adalah kurangnya pemantauan dan perbaikan proses yang berkesinambungan akan membuat proses terdegradasi. Hal ini sesuai dengan prinsip kontinuitas dalam 10 prinsip BPM menurut (Vom Brocke et al., 2014), yang menyatakan bahwa BPM adalah siklus kontinu dan bukan proyek satu kali.

\subsection{Hipotesis}

- Aktor (actors), yaitu manusia, organisasi, perangkat lunak yang menjalankan tugas bagi manusia atau organisasi, obyek fisik seperti peralatan, material, produk, dokumen, dan obyek lain yang bukan material, seperti dokumen elektronik dan catatan elektronik.

- Hasil (outcome) yang idealnya membawa nilai bagi actor yang terlibat dalam proses yang disebut hasil positif, namun proses mungkin hanya mampu mendapatkan sebagian nilai yang diharapkan atau tidak mendatangkan nilai sama sekali. Dalam kondisi ini, proses disebut membawa hasil negative.

Menurut Hammer (2015) terdapat beberapa prinsip yang menjadi dasar pentingnya manajemen proses, antara lain:

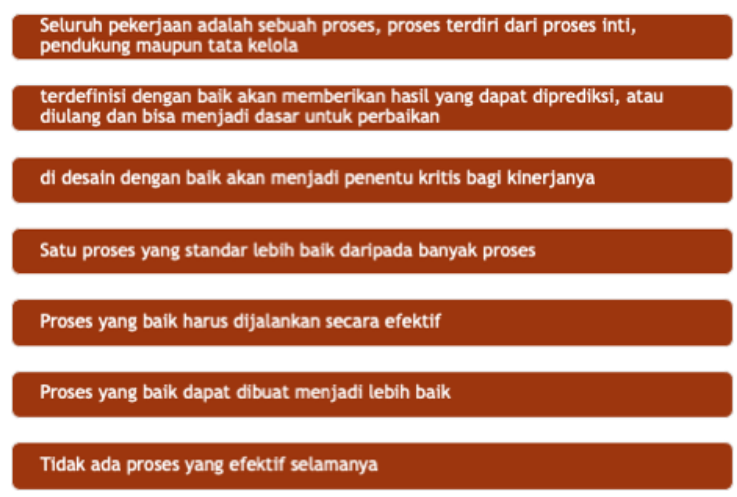

\subsection{Siklus Hidup BPM}

DOI: $10.52362 /$ jisicom.v5i1.381

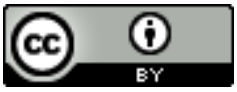

Ciptaan disebarluaskan di bawah Lisensi Creative Commons Atribusi 4.0 Internasional. 
Journal of Information System, Informatics and Computing

Website/URL: http://journal.stmikjayakarta.ac.id/index.php/iisicom

Email: jisicom@stmikjayakarta.ac.id , jisicom2017@gmail.com

Dumas et al., (2013) memasukkan keterkaitan antara BPM dengan kebutuhan organisasi secara keseluruhan melalui tahap identifikasi proses dan mengusulkan pemantauan dan pengendalian proses yang dapat mengarah pada keberlanjutan BPM.

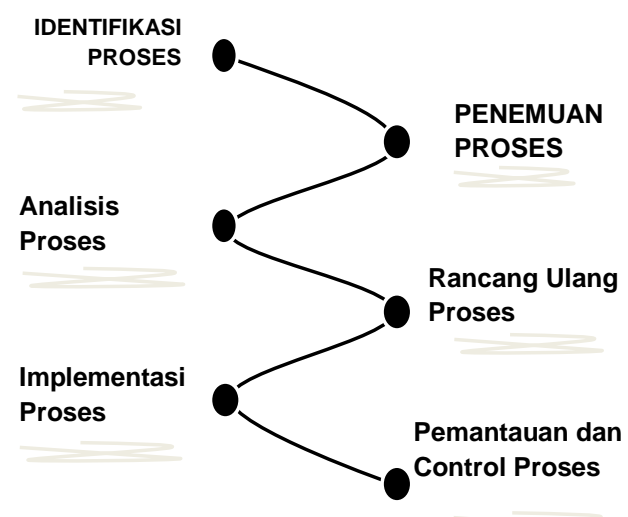

\subsection{Design Proses dan Identifikasi Proses}

Hasil identifikasi proses adalah arsitektur proses (process architecture) baru atau yang diperbarui, yang memberikan keseluruhan pandangan proses dalam sebuah organisasi dan hubungan mereka. Arsitektur proses merupakan model konseptual yang menggambarkan proses-proses dan keterkaitan hubungan antar proses dalam perusahaan. (Dijkman et al., 2011) dalam (Mahendrawathy, 2018) menyebutkan arsitektur proses terbagi menjadi tiga level, yaitu process landscape, abstract process models, dan detailed process models.

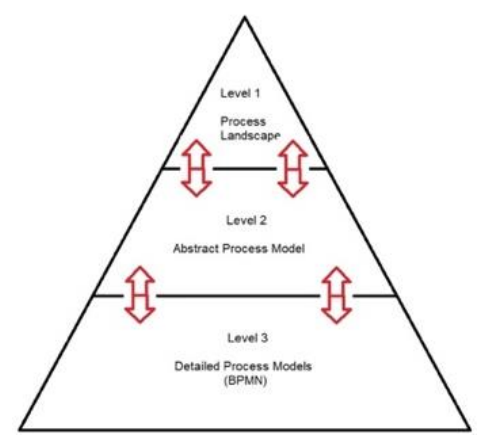

\section{PEMBAHASAN DAN HASIL}

\subsection{Penemuan Proses}

a. Penemuan berbasis bukti-bukti

Bukti bisa didapatkan melalui analisis dokumen, observasi, maupun penemuan proses otomatis dari sistem informasi yang ada

b. Penemuan berbasis wawancara

berpedoman pada hasil wawancara kepada ahli bidang tentang bagaimana sebuah proses dijalankan

c. Penemuan berbasis workshop

melibatkan lebih banyak partisipan dengan berbagai peran untuk mendiskusikan tentang proses bisnis saat

DOI: $10.52362 /$ jisicom.v5i1.381

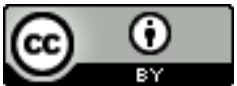

Ciptaan disebarluaskan di bawah Lisensi Creative Commons Atribusi 4.0 Internasional. 
Journal of Information System, Informatics and Computing

Website/URL: http://journal.stmikjayakarta.ac.id/index.php/jisicom

Email: jisicom@stmikjayakarta.ac.id , jisicom2017@gmail.com

ini

Fase dalam Penemuan Proses :

Fase 1: Menentukan setting.

fase ini perusahaan membentuk tim yang akan bertanggung jawab dalam menangani proses.

Fase 2 : Mengumpulkan informasi.

fase ini berusaha untuk memahami proses dengan berbagai cara untuk mendapatkan informasi tentang proses.

Fase 3 : Melakukan aktivitas pemodelan.

fase ini terkait dengan usaha mengorganisasikan pembuatan model. Metode pemodelan memberikan petunjuk untuk pemetaan proses secara sistematis .

Fase 4 : Memastikan kualitas model.

fase ini berusaha memastikan bahwa hasil pemodelan memenuhi berbagai kriteria kualitas. Hal ini dibutuhkan untuk menciptakan kepercayaan pada model proses.

\subsection{Analisis Proses}

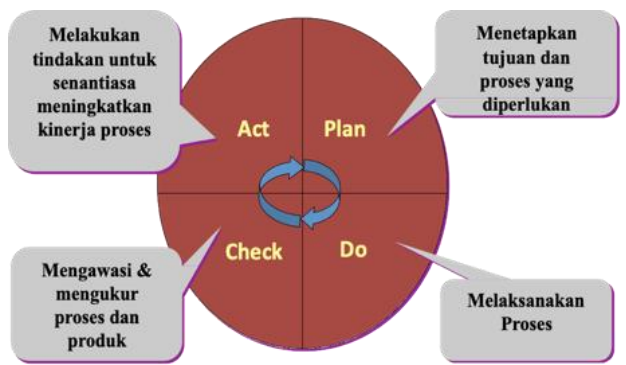

Sebuah filosofi proses manajemen | PDCA

Secara umum, Dumas et al. membagi analisis proses menjadi:

1. analisis kualitatif

2. analisis kuantitatif

\section{Analisis kualitatif}

Pendekatan analisis kualitatif dapat dikelompokkan menjadi: Prinsip-prinsip yang bertujuan untuk membuat proses menjadi lebih ringkas atau tidak ada pemborosan. Beberapa prinsip dalam kelompok ini adalah Value Added Analysis. Prinsip-prinsip untuk menganalisis bagian-bagian dari proses yang lemah, menimbulkan masalah yang berpengaruh buruk pada kinerja proses. Teknik yang dapat digunakan adalah Root Cause Analysis.

\section{Value Added Analysis}

Value Added Analysis merupakan teknik analisis yang yang terdiri dari dua bagian penting yaitu, Value Classification dan Waste Elimination. Dalam Value Classification akan dilakukan identifikasi setiap aktivitas dalam sebuah proses ke dalam beberapa kategori sebagai berikut :

* Value Adding (VA)

Aktivitas yang termasuk ke dalam kategori ini adalah aktivitas yang menghasilkan nilai atau secara langsung berkontribusi dalam memuaskan pelanggan.

\section{* Business Value Adding (BVA)}

Aktivitas yang termasuk ke dalam kategori ini adalah aktivitas yang penting dan berguna untuk keberlangsungan bisnis namun tidak secara langsung berkontribusi dalam memuaskan kebutuhan pelanggan.

DOI: $10.52362 /$ jisicom.v5i1.381

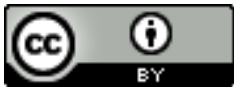

Ciptaan disebarluaskan di bawah Lisensi Creative Commons Atribusi 4.0 Internasional. 
Journal of Information System, Informatics and Computing

Website/URL: http://journal.stmikjayakarta.ac.id/index.php/jisicom

Email: jisicom@stmikjayakarta.ac.id , jisicom2017@gmail.com

\section{* Non Value Adding (NVA)}

Aktivitas yang termasuk ke dalam kategori ini adalah aktivitas yang tidak termasuk ke dalam kedua kategori di atas.

Setelah melakukan Value Classification, hal yang dilakukan berikutnya adalah Waste Elimination. Dalam Waste Elimination akan dilakukan eliminasi terhadap aktivitas-aktivitas di dalam proses yang tidak menambah nilai. Langkah pertama yang harus dilakukan dalam Waste Elimination adalah menghilangkan aktivitas yang masuk ke dalam kategori Business Value-Adding (BVA). Untuk menghilangkan aktivitas BVA perlu adanya pemetaan terhadap tujuan bisnis dan kebutuhan bisnis. Mengingat aktivitas BVA ini merupakan aktivitas-aktivitas yang perlu untuk keberlangsungan bisnis.

\section{Root Cause Analysis}

Root Cause Analysis merupakan teknik untuk membantu analis mengidentifikasi dan memahami akar masalah dari sebuah permasalahan. Ada banyak variasi teknik dari Root Cause Analysis.

\section{Cause Effect Diagrams}

Cause-Effect Diagram sering juga disebut sebagai Fish Bone Diagram atau Ishikawa Diagram adalah teknik yang cukup banyak dikenal dalam analisis permasalahan. Diagram ini menggambarkan hubungan antara sebuah efek negative dan penyebabnya. Dalam konteks analisis proses, sebuah efek negatif umumnya adalah masalah yang terjadi saat ini atau ketidaksesuaian kinerja proses.

\subsection{Rancang Proses.}

Business Process Re-Engineering (BPR)

Re-design business dengan masif terhadap proses inti dilakukan untuk mencapai peningkatan pada Produktivitas, Waktu Siklus dan Kualitas.

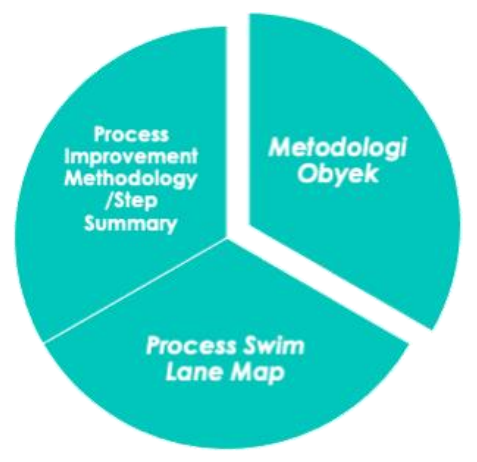

\section{Swim Lane Map Process}

Swim Lane Map merupakan suatu sistem tradisional untuk merencanakan pelaksanaan suatu kegiatan secara menyeluruh yang sudah di peta kan dari sisi waktu, jenis pekerjaan dan fungsi dari pelaksana pekerjaan tersebut yang di buat secara manual sistematis dengan proses-proses yang ditulis secara jelas dan rinci. Dokumen tersebut memang dibuat secara hardcopy dan menjadi dasar sebuah rencana pelaksanaan kegiatan secara menyeluruh yang dapat di kendalikan dan di monitoring dengan baik.

\section{Improvement Methodology - Rapid Process}

Adalah suatu methodology yang dilakukan secara singkat untuk melakukan penilaian dan perbaikan dalam suatu proses yang telah dilakukan. Ada beberapa langkah yang perlu dilakukan untuk hal tersebut, yaitu:

- Membuat alur proses yang sudah dilakukan.

- Melakukan diskusi dan wawancara terhadap pemilik proses.

- Menganalisa kinerja proses.

DOI: $10.52362 /$ jisicom.v5i1.381

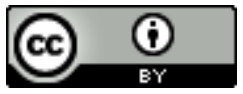

Ciptaan disebarluaskan di bawah Lisensi Creative Commons Atribusi 4.0 Internasional. 
Journal of Information System, Informatics and Computing

Website/URL: http://journal.stmikjayakarta.ac.id/index.php/jisicom

Email: jisicom@stmikjayakarta.ac.id , jisicom2017@gmail.com

- Menangkap peluang perbaikan yang akan dilakukan.

- Merancang rencana proses berikutnya dan melakukan perbandingan.

- Membuat laporan secara komprehensif terhadap rekomendasi usulan perbaikan yang akan di lakukan.

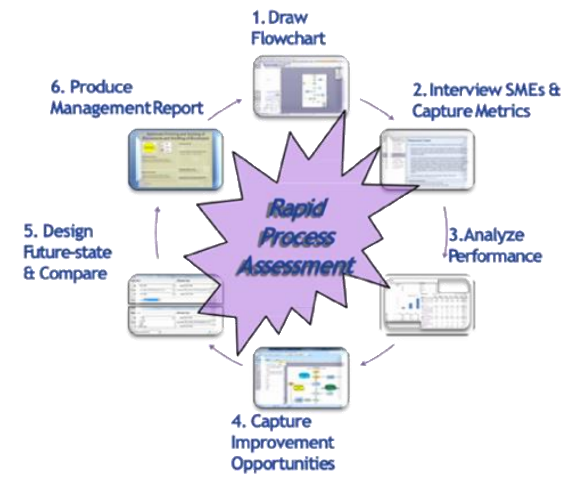

Penilaian yang dilakukan secara singkat juga mendukung suatu manajemen proses yang berbasis DMAIC(Define, Measure, Analyze, Improve, Control)Ada beberapa Langkah yang perlu dilakukan yaitu:

- Membuat dan mendefinisikan alur proses saat ini.

- Mengkonfigurasi alur proses dengan beberapa atribut dan karakteristik seperti waktu,sumber daya, dll.

- Menganalisa kinerja proses saat ini.

- Mendisain Perbaikan proses saat ini dan membandingkan dengan proses mendatang serta melakukan validasi kepada manajemen.

- Memonitor proses saat ini dan melakukan siklus perbaikan sesuai dengan kebutuhan bisnis.

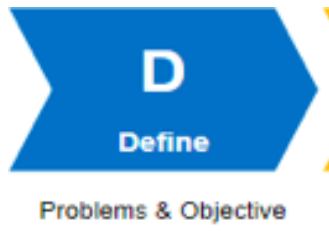

Metodologi Obyek

Pengembangan bisnis perusahaan selain dari rencana strategis yang dibuat dan dipetakan adalah menyiapkan dan menerapkan kesesuaian proses bisnis yang akan diimplementasikan di korporat. Ada beberapa hal yang menjadi kunci penting, sebagai langkah persiapan yang akan dilakukan sebagai metode yang digunakan untuk melakukan pengembangan proses bisnis mendatang. Visi, Misi, Proses Inti, Strategi dan Kebijakan Perusahaan serta arah bisnis merupakan kompas yang menjadi pengarah awal terhadap perkembangan yang terjadi pada suatu perusahaan. Perlu dilakukan penilaian terhadap kondisi model bisnis saat ini dengan beberapa tahapan yaitu: Analisa, Identifikasi dan Interaksi terhadap kegiatan dan kinerja yang telah dilakukan saat ini. Diperlukan suatu rencana dan rangkaian perbaikan secara menyeluruh untuk menjelaskan langkah-langkah yang perlu di kembangkan dan ditingkatkan, mulai dari masing-masing satuan kerja hingga interaksi antar satuan kerja di dalam organisasi, sehingga proses yang dilakukan bisa lebih terukur dan terdokumentasi secara berkelanjutan

3.4. Implementasi Proses

Proses Inti merupakan kunci utama dalam mengeksekusi rencana-rencana obyektif dan tujuan korporat. Untuk mendapatkan hasil yang baik dan terukur, maka rencana strategi bisnis dan pelaksanaan proses dilakukan melalui 2 phase, yaitu:

\section{Phase Planning}

- Strategy

DOI: $10.52362 /$ jisicom.v5i1.381

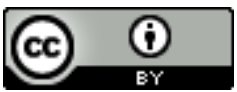

Ciptaan disebarluaskan di bawah Lisensi Creative Commons Atribusi 4.0 Internasional. 
Journal of Information System, Informatics and Computing

Website/URL: http://journal.stmikjayakarta.ac.id/index.php/jisicom

Email: jisicom@stmikjayakarta.ac.id , jisicom2017@gmail.com

- Operating Plan

- Goals and Objectives

Phase Execution

Melakukan Analisa dan pengembangan terhadap proses inti, untuk dijadikan masukan utama perbaikan proses bisnis mendatang.

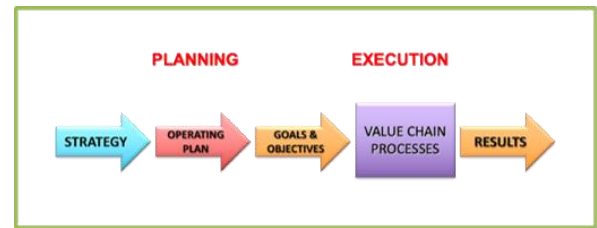

Identifikasi Proses Bisnis Inti (core)

* Mengidentifikasi proses-proses bisnis terkait layanan-layanan produk Klasifikasi \& jenis nya.

* Mengidentifikasi proses-proses bisnis terkait layanan-layanan produk Komersial.

* Mengidentifikasi standar-standar yang digunakan dalam pemberian layanan-layanan Klasifikasi dan Jenis Komersial.

* Memodelkan tiap-tiap proses bisnis secara end-to-end.

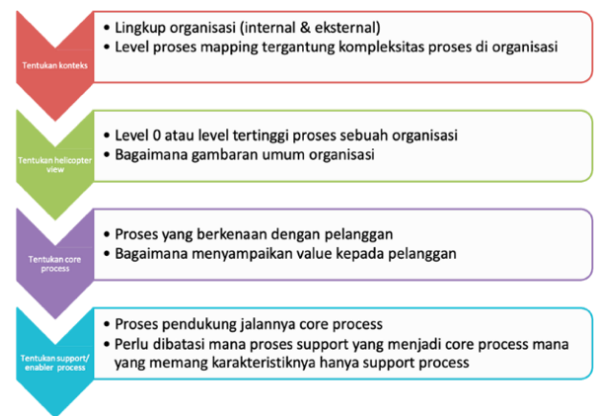

Proses bisnis adalah merupakan hasil kolaborasi dari proses inti, organisasi, strategi dan arah kebijakan perusahaan serta budaya perusahaan sehingga kepentingan Pemegang Saham, Pemangku kepentingan dan Pelanggan menjadi nilai utama yang terus dikembangkan. Target Strategi besar yang akan dipersiapkan dan dilakukan di dalam kebijakan, komitmen dan target perusahaan. Sebuah perusahaan dengan visi dan misi yang telah ditetapkan akan melakukan penyesuaian dengan komponen-komponen penting di dalam perusahaan untuk mendukung sistematika proses kerja di internal perusahaan. Rencana jangka panjang, menengah dan pendek yang telah disiapkan akan di terjemahkan ke dalam pilar-pilar bisnis perusahaan, yang di dukung oleh Infrastruktur yang handal di berbagai wilayah, tenaga kerja yang professional, berbagai fasilitas yang mendukung pengembangan-pengembangan prospek masa mendatang serta penggunaan teknologi terupdate yang dapat menjembatani informasi. Seluruhnya merupakan suatu Ekosistem Bisnis yang dipersiapkan untuk saat ini dan mendatang.

\section{Business Model (Helicopter View)}

DOI: $10.52362 /$ jisicom.v5i1.381

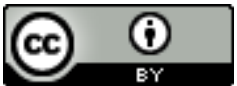

Ciptaan disebarluaskan di bawah Lisensi Creative Commons Atribusi 4.0 Internasional. 


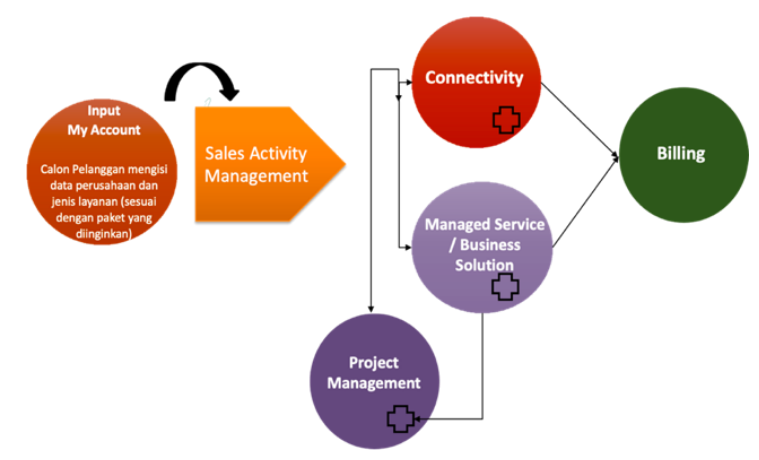

Business Process Management PT PGAS Telekomunikasi Nusantara terdiri atas 5 level proses yaitu :

- Level 0 : Helicopter View atau bagaimana organisasi melihat tata kelola organisasinya dari sudut pandang makro

- Level 1 : Process Dashboard atau Proses - proses yang menjadi indikator besar di dalam menjalankan organisasinya.

- Level 2 : Process Panel atau interaksi antar proses - proses utama dari satu satuan kerja ke satuan kerja lain yang saling terkait

- Level 3 : Interaksi antar proses dari suatu satuan kerja tertentu atau proses-proses utama yang saling berinteraksi di dalam satu satuan kerja

- Level 4 : Aktivitas menjalankan proses dari satu satuan kerja yang melibatkan personil dengan jabatan tertentu.

\section{Output Model}

Helicopter View (BPM Level 0)

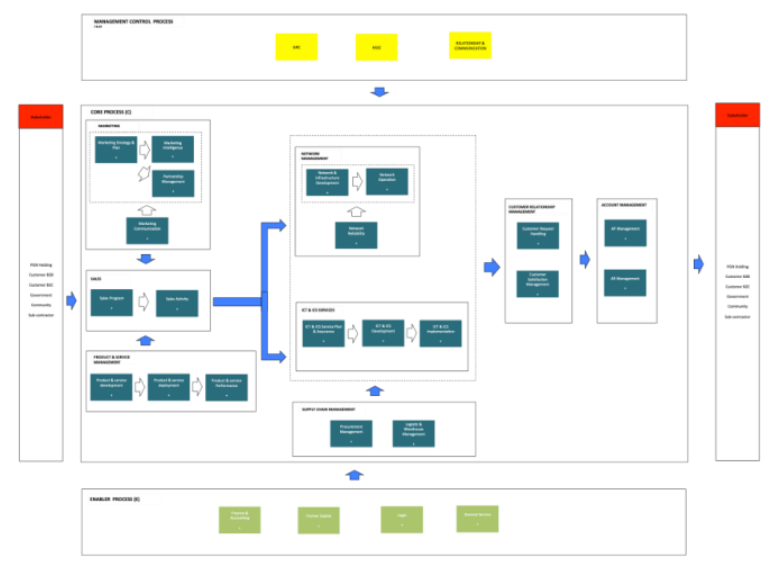

Output Model
BPM Level (1-3)

DOI: $10.52362 /$ jisicom.v5i1.381

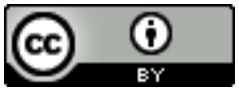

Ciptaan disebarluaskan di bawah Lisensi Creative Commons Atribusi 4.0 Internasional. 
Journal of Information System, Informatics and Computing

Website/URL: http://journal.stmikjayakarta.ac.id/index.php/jisicom

Email: jisicom@stmikjayakarta.ac.id , jisicom2017@gmail.com

\section{Output Model}

BPM Level 4
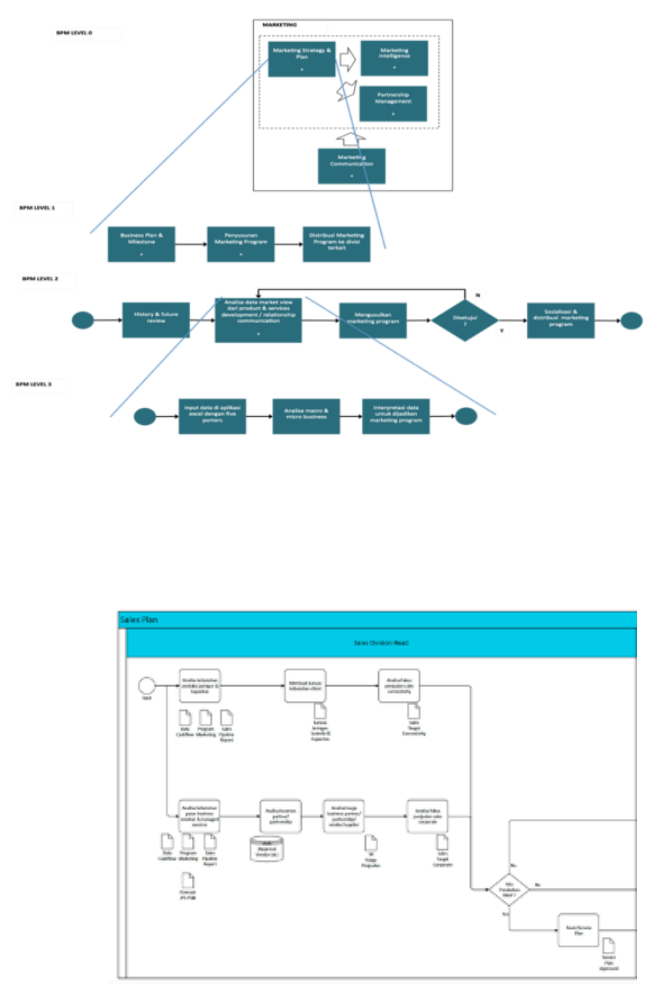

Boleh dikatakan Level 0, Level 1 dan Level 2 adalah Strategic Business Organisasi, sementara Level 3 dan Level 4 adalah bagaimana menjalankan strategic business organisasi tersebut di masing-masing satuan kerja.

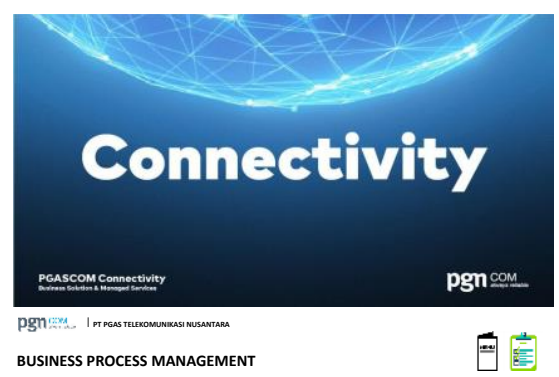

\subsection{Pemantauan Kontrol Proses}

Organisasi harus menyeimbangkan antara sumber daya perubahan (change resources) dan infrastruktur dengan kebutuhan akan perubahan, termasuk review perubahan baik dari perspektif makro (organisasi) maupun mikro (individu/SDM)

Kepemimpinan, navigasi yang memadai, stakeholder ownership dan efektivitas pemberdayaan dengan strategi yang optimal adalah kunci perubahan itu sendiri. Perubahan merupakan langkah transaksi yang harus dikelola dengan fokus pada sasaran antara sebagaimana sasaran akhir organisasi. Organisasi akan mentransformasikan dirinya secara terus menerus (berkelanjutan) dan mesti meminimalisir dampak terhadap proses bisnis yang sedang berjalan melalui perencanaan serta eksekusi yang bertahap, yaitu :

- Identifikasi strategic view bisnis organisasi.

- Fokus pada suatu masalah di uraian proses.

- Identifikasi improvement pada proses, policy, biaya, pengukuran, people, dan lain-lain.

DOI: $10.52362 /$ jisicom.v5i1.381

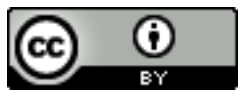

Ciptaan disebarluaskan di bawah Lisensi Creative Commons Atribusi 4.0 Internasional. 
Journal of Information System, Informatics and Computing

Website/URL: http://journal.stmikjayakarta.ac.id/index.php/jisicom

Email: jisicom@stmikjayakarta.ac.id , jisicom2017@gmail.com

- Merumuskan pengukuran proses /SLA.

- Bisnis model sesuai dengan enterprise proses dan mengurangi pemborosan.

- Process Inti bisa dilakukan menyeluruh.

- SOP bisa terintegrasi.

- Dapat dilakukan pengukuran proses ataupun kinerja.

- Job Description sesuai dengan enterprise proses.

- Peningkatan Layanan Pelanggan.

Dalam memodelkan Proses bisnis perlu adanya suatu Standard Operating Procedure yang harus dimiliki oleh setiap perusahaan. Standard Operating Procedure adalah dokumen yang berkaitan dengan prosedur yang dilakukan secara kronologis untuk menyelesaikan suatu pekerjaan yang bertujuan untuk memperoleh hasil kerja yang paling efektif dari para pekerja dengan biaya serendah-rendahnya sekaligus mengurangi miskomunikasi dan kegagalan dalam mematuhi peraturan perusahaan. (Huda et al., 2016) dalam (Riyanarto et al., 2017).

Ada 3 tujuan pembuatan procedure atau SOP:

a) SOP untuk define process dan klarifikasi tugas berguna untuk organisasi yang belum memiliki SOP dan belum jelas tugas dan tanggung jawabnya dan menjalankan kebijakan yang ada. Level terendah di maturity process (define process).

b) SOP for compliance

Disamping untuk klarifikasi digunakan untuk memenuhi persyaratan standard, peraturan, dan persyaratan pelanggan. (Standard Minimum, ISO, UU, Kepmen, dsb).

c) SOP for Improvement.

1. SOP dibuat setelah ide improvement disetujui dan siap untuk dijalankan.

2. Focus pada process terntentu saja.

3. Improvement idea dapat dari masalah- masalah yang timbul sehingga membutuhkan rencana perbaikan atau corrective action.

4. Improvement idea dapat juga dari kesadaran untuk meningkatkan proses yang ada.

\section{ALUR PEMBUATAN SOP}

(Standard Operating Procedure)
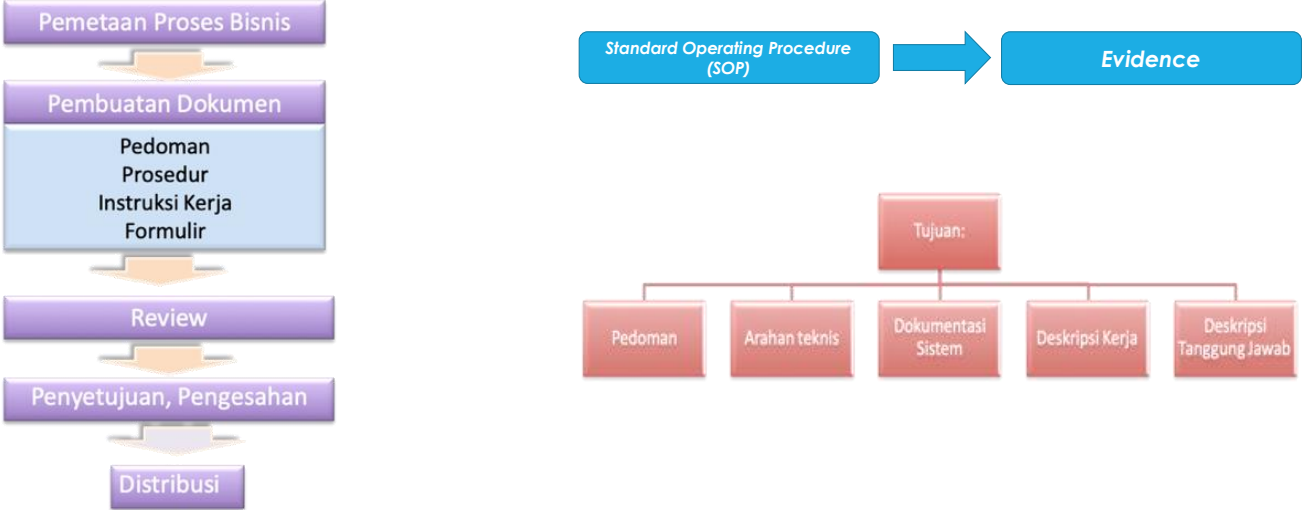

Objektif Business Process Re-Engineering (BPR)

BPR berfokus pada bagaimana proses kerjanya bukan pada siapa yang melakukan.

- Menggunakan who (orang) untuk menentukan proses kerjanya.

- Mengurangi pemborosan proses (waste).

- Menyederhanakan semua proses yang ada.

DOI: $10.52362 /$ jisicom.v5i1.381

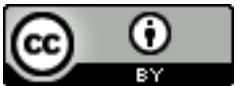

Ciptaan disebarluaskan di bawah Lisensi Creative Commons Atribusi 4.0 Internasional. 
Journal of Information System, Informatics and Computing

Website/URL: http://journal.stmikjayakarta.ac.id/index.php/jisicom

Email: jisicom@stmikjayakarta.ac.id , jisicom2017@gmail.com

- Kombinasi beberapa langkah dalam proses.

- Mendesain proses dengan metode alternatif lain.

- Mengikutsertakan customer \& supplier dalam proses.

- Menggunakan teknologi untuk meningkatkan kinerja prosesnya.

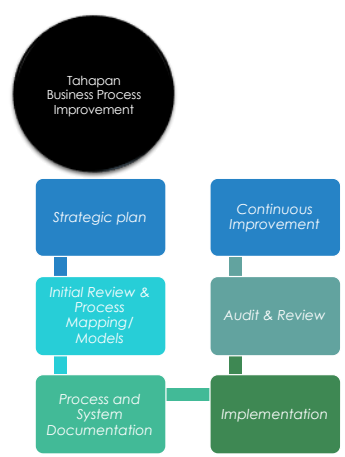

\section{TAHAPAN BUSINESS PROCESS IMPROVEMENT}

1. Phase I: Strategic plan

2. Phase II: Initial Review \& Process Mapping/Models

3. Phase III: Process and System Documentation

4. Phase IV: Implementation

5. Phase V: Audit \& Review

6. Phase VI: Continuous Improvement

Perbaikan Bertahap Proses Kerja Dari Kondisi Sebelumnya dan Peningkatan Kehandalan System

Tree diagram merupakan teknik untuk menganalisis penyebab dari suatu efek negatif seperti masalah dalam proses bisnis. Penekanan dalam Root Cause Analysis adalah untuk mendapatkan serangkaian hubungan sebab akibat yang menimbulkan efek tertentu. Ide dasarnya adalah untuk secara berulang menanyakan "mengapa hal itu terjadi? sampai faktor yang dianggap oleh stakeholder sebagai akar masalah ditemukan. Aturan praktis di bidang manajemen kualitas, yang dikenal dengan 5 why's principles, adalah dengan menjawab lima pertanyaan "why" memungkinkan kita untuk menemukan akar permasalahan dari suatu efek negatif. Why-why diagram juga merupakan teknik untuk menstruktur sesi brainstorming. Sesi ini biasanya diawali dengan sebuah masalah. Seluruh peserta diskusi harus memberikan nama untuk masalah Itu. jika terdapat lebih dari satu masalah, tiap masalah harus dianalisis secara terpisah. Masalah yang ditentukan menjadi akar dari pohon, kemudian setiap tingkatan ditanyakan "mengapa hal ini terjadi?" dan "apa sub-permasalahan yang berkontribusi pada masalah tersebut? Faktor-faktor yang mungkin kemudian didaftar dan dianalisis menggunakan persamaan yang sama.

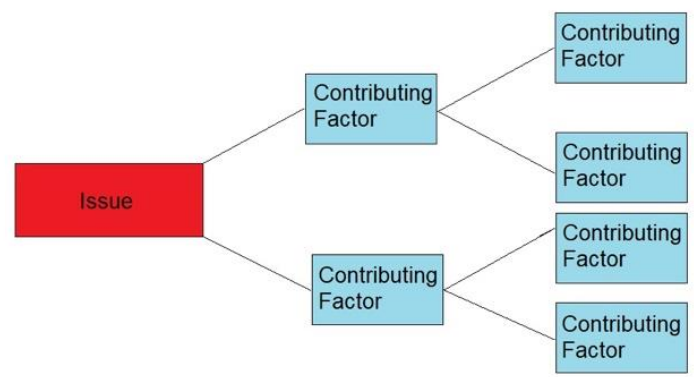

Issue Documentation and Impact Assessment

DOI: $10.52362 /$ jisicom.v5i1.381

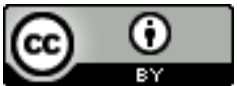

Ciptaan disebarluaskan di bawah Lisensi Creative Commons Atribusi 4.0 Internasional. 
Journal of Information System, Informatics and Computing

Website/URL: http://journal.stmikjayakarta.ac.id/index.php/jisicom

Email: jisicom@stmikjayakarta.ac.id , jisicom2017@gmail.com

Pada umumnya setelah melakukan Root Cause Analysis, langkah selanjutnya adalah menuliskan setiap permasalahan dalam Issue Register dan memahami dampak-dampaknya. Hal ini bertujuan untuk memahami permasalahan mana yang harus diprioritaskan dan diperhatikan secara khusus.

\section{Issue Register}

Issue Register melengkapi hasil keluaran dari Root Cause Analysis dalam bentuk Analisis yang lebih detail beserta dampaknya. Dampak dari sebuah permasalahan dapat dideskripsikan secara kuantitatif. Issue Register mengandung informasi, sebagai berikut:

- Nama permasalahan.

- Deskripsi.

- Prioritas.

- Asumsi (atau data masukan).

- Dampak kualitatif.

- Dampak kuantitatif.

\section{Pareto Analysis dan Pick Chart}

Penilaian dampak yang dilakukan saat membangun issue register dapat menjadi input untuk analisis pareto. Tujuan dari analisis Pareto adalah untuk mengidentifikasi masalah-masalah atau faktor penyebab yang harus diberikan prioritas dengan keterbatasan kapabilitas dan sumber daya yang dimiliki perusahaan. Analisis Pareto berdasarkan prinsip bahwa hanya sedikit faktor berkontribusi besar pada suatu dampak. Prinsip ini juga dikenal dengan aturan 80-20, di mana hanya $20 \%$ dari masalah berkontribusi pada $80 \%$ dari dampak. Namun, perlu diingat bahwa proporsi 80-20 ini hanya indikasi dan bukan patokan yang kaku.

Tahapan-tahapan umum dalam membuat diagram Pareto adalah:

o Tentukan efek atau dampak yang akan dianalisis dan metrik untuk mengkuantifikasi efek tersebut. Metrik bisa berupa kerugian biaya bagi perusahaan, waktu yang terbuang, jumlah pelanggan yang tidak puas karena kesalahan dalam melayani. Identifikasi berbagai masalah yang berkontribusi pada efek yang dianalisis.

o Kuantifikasi tiap masalah berdasarkan metrik yang sudah ditentukan. Langkah ini dapat dilakukan berdasarkan atas issue register, terutama bagian dampak kuantitatif. Urutkan masalah berdasarkan ukuran yang dipilih mulai dari yang berdampak tertinggi sampai terendah, dan gambarkan dalam Pareto chart. Sebuah diagram pareto terdiri dari dua komponen, yakni: Diagram batang di mana tiap batang mewakili sebuah masalah dan tinggi batang proporsional terhadap dampak dari faktor tersebut, dan sebuah kurva yang menunjukkan prosentase kumulatif dari dampak tiap masalah.

Analisis Pareto fokus pada satu dimensi saja. Padahal kenyataannya, dalam memutuskan masalah yang harus diprioritaskan, juga perlu mempertimbangkan tingkat kesulitan dalam menangani suatu masalah. Tingkat kesulitan ini dapat dikuantifikasi dalam bentuk besarnya investasi yang dibutuhkan untuk mengubah proses agar dapat mengatasi masalah. Oleh karena itu, Pick Chart digunakan untuk melengkapi Pareto. Pick Chart adalah sebuah diagram empat kuadran di mana masalah dimunculkan sebagai sebuah titik yang diletakkan di dalam kuadran. Sumbu horizontal menunjukkan tingkat kesulitan menerapkan ide perbaikan yang dapat mengatasi masalah. Sumbu horizontal dibagi menjadi dua bagian yaitu mudah dan sulit. Sementara, sumbu vertikal menunjukkan hasil yang diharapkan dan dibagi menjadi bagian yang rendah dan tinggi. Berdasarkan pembagian ini akan di dapat empat kuadran:

a) Mungkin adalah ide perbaikan yang mudah diterapkan namun hasil yang diharapkan rendah. Masalah ini dapat ditangani jika ada sumber daya yang mencukupi.

b) Implementasi adalah ide yang mudah dijalankan dan hasil yang diharapkan tinggi. Masalah ini harus diprioritaskan untuk diimplementasikan.

DOI: $10.52362 /$ jisicom.v5i1.381

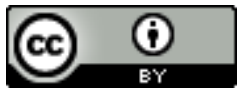

Ciptaan disebarluaskan di bawah Lisensi Creative Commons Atribusi 4.0 Internasional. 
c) Kill adalah ide yang sulit diterapkan dan hasilnya rendah. Masalah ini mungkin tidak setimpal untuk ditangani.

d) Menantang adalah ide yang harus di atasi karena dapat membawa hasil yang baik namun membutuhkan sumber daya yang besar.

Umumnya, perusahaan akan memilih salah satu dari masalah pada Kuadran ini dan fokus untuk menyelesaikannya daripada berusaha mengatasi banyak masalah pada saat yang bersamaan.

\section{Analisis Kuantitatif}

Analisis kualitatif adalah alat yang bermanfaat untuk mendapatkan wawasan tentang sebuah proses. Namun, hasil dari analisis kualitatif sering kali tidak cukup detail untuk menjadi dasar pengambilan keputusan. Oleh karena itu, Dumas et al. juga memperkenalkan berbagai teknis untuk menganalisis proses bisnis secara kuantitatif terkait dengan ukuran kinerja tertentu. Umumnya ukuran kinerja yang dianalisis adalah:

a. Waktu, misalnya waktu siklus, yaitu waktu yang dibutuhkan untuk menangani sebuah kasus dari awal sampai akhir. Ukuran lain terkait waktu adalah waktu tunggu dan waktu pemrosesan.

b. Biaya adalah segala ukuran yang terkait dengan kinerja finansial baik berupa pemasukan, keuntungan, ataupun perputaran uang.

c. Kualitas dari proses bisnis dapat dilihat sisi dari pelanggan maupun dari sisi pelaksana proses. Dari sisi pelanggan, kualitas dapat diukur dari kepuasan pelanggan; sementara kualitas internal dapat dilihat dari sejauh mana pelaksana proses mengendalikan pekerjaan yang dilakukan.

d. Fleksibilitas adalah kemampuan untuk berinteraksi terhadap perubahan.

\section{Flow Analysis}

Flow analysis atau analisis aliran adalah sekumpulan teknik yang dapat digunakan untuk mengestimasi keseluruhan kinerja dari proses berdasarkan atas pengetahuan tentang kinerja dari aktivitas-aktivitas di dalam proses tersebut.

\section{Queue}

Queue atau antrian adalah sekumpulan teknik matematis untuk menganalisis sistem yang memiliki batasan sumber daya. Sumber daya yang terbatas secara tidak di sengaja akan menimbulkan antrean seperti yang kita alami di bank, kantor pelayanan publik, apotek, supermarket, dl. Teknik antrean memungkinkan kita melakukan analisis parameter penting dari antrean seperti perkiraan panjang antrean atau waktu tunggu dari setiap orang di dalam antrean.

\section{Simulasi}

Simulasi adalah teknik yang umum digunakan untuk analisis kuantitatif dari model proses. Ide dasarnya adalah sebuah simulator proses membangkitkan contoh-contoh hipotetis dalam jumlah besar dari sebuah proses, menjalankan contoh ini langkah demi langkah, kemudian mencatat tiap contoh dalam pelaksanaan. Luaran dari simulator biasanya berupa catatan dari simulasi dan statistik terkait dengan waktu siklus, rata-rata waktu tunggu, dan rata-rata utilisasi sumber daya.

\section{Perancangan ulang Proses}

Fase ini juga disebut fase perbaikan proses. Tujuan dari tahap ini adalah untuk mengidentifkasi perubahan pada proses yang akan membantu mengatasi masalah yang diidentifkasi pada fase sebelumnya dan memungkinkan organisasi memenuhi tujuan kinerjanya. Untuk mencapai tujuan ini, beberapa opsi perubahan dianalisis dan dibandingkan dalam hal ukuran kinerja yang dipilih.

Dumas et al. membedakan dua metodologi untuk perancangan ulang:

DOI: $10.52362 /$ jisicom.v5i1.381

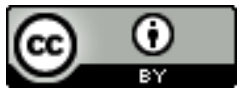

Ciptaan disebarluaskan di bawah Lisensi Creative Commons Atribusi 4.0 Internasional. 


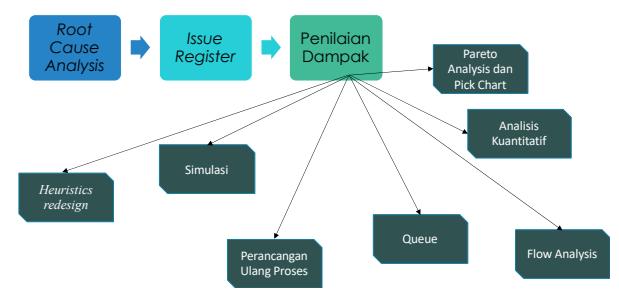

- re-design heuristics yang berawal dari proses saat ini untuk mencapai perbaikan kinerja secara bertahap; dan

- product-based design yang dimulai dari kertas yang kosong untuk menghasilkan rancangan proses yang lebih baik

secara

radikal

\section{KESIMPULAN}

Penerapan Manajemen Proses Bisnis yang di tetapkan di perusahaan yaitu :

1. Continuous Process Improvement (CPI) :

Mengidentifikasi masalah dan menye-lesaikannya secara bertahap yaitu: menganalisa, melaksanakan dan memantau proses bisnis.

2. Business Process Re-engineering (BPR) :

Mempertanyakan asumsi dan prinsip dasar dari proses yang sudah ada yang bertujuan untuk mencapai terobosan, misalnya dengan peng-hapusan tugas yang memakan biaya banyak dan tidak secara langsung menambah nilai atau sebaliknya menambahkan proses perbaikan agar mendapatkan nilai tambah.

Simpulan terhadap Analisa Pareto dan Pick Chart, kualitatif dan kuantitatif, flow analysis, queue, simulasi dan perancangan ulang design tersebut, saya menyimpulkan adanya kolaborasi secara menyeluruh, yaitu dengan memprioritaskan secara bertahap sesuai Tabel Heuristic Process Redesign dengan perbaikan proses kerja dari kondisi sebelum nya dan peningkatan kehandalan sistem untuk menunjang kinerja yang juga dikembangkan di dalam perusahaan, sehingga terdapat monitoring berkala dan berkelanjutan yang dilakukan dari sisi Quality dan Audit Proses dalam Perusahaan. Perubahan proses dilakukan dengan tujuan untuk menghasilkan/ menambah nilai bisnis perusahaan.

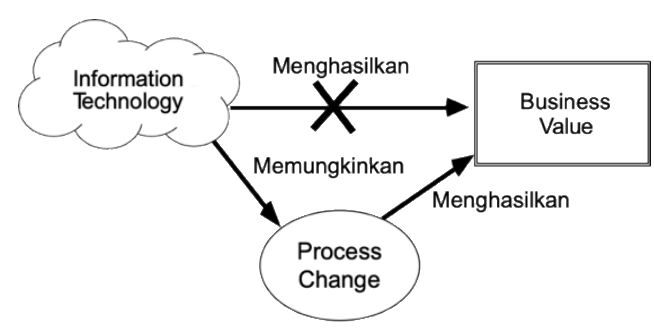

\section{SARAN}

1. Membutuhkan Continuous Corrective actions (Melibatkan para pemilik proses), yaitu dengan menentukan penanggung jawab process (process owner)

2. Untuk Preventive actions dan Inovasi membutuhkan tim kecil (process champion), namun harus melibatkan seluruh pemilik process juga. (Improvement Team), untuk inovasi yang lain dapat dilakukan oleh Tim Khusus.

3. Fokus pada proses tertentu.

Key success continuous improvement :

- Top management commitment:

DOI: $10.52362 /$ jisicom.v5i1.381

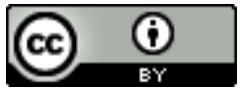

Ciptaan disebarluaskan di bawah Lisensi Creative Commons Atribusi 4.0 Internasional. 
Journal of Information System, Informatics and Computing

Website/URL: http://journal.stmikjayakarta.ac.id/index.php/iisicom

Email: jisicom@stmikjayakarta.ac.id , jisicom2017@gmail.com

- Vision, mission and policy.

- Objective and target.

- Sense of urgency.

- Tahapan (Phase) yang benar.

- Pemilihan scope yg sesuai.

- Training \& Coaching.

- Internal consultant (Task Force Team/Team BPM).

- Involvement of people (keterlibatan).

- Working party (Pemilik proses):

- Communication

- Sense of urgency.

- Top down and bottom up. (make example, create the matrix).

- Supported by People Management yang sesuai.

- Competency yang sesuai.

- Proses-proses Manajemen Proses (process management governance).

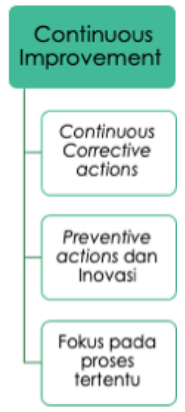

Improvement berfokus pada bagaimana proses kerjanya bukan pada siapa yang melakukan, yaitu:

- Menggunakan who (orang) untuk menentukan proses kerjanya.

- Mengurangi pemborosan proses (waste).

- Menyederhanakan semua proses yang ada.

- Kombinasi beberapa langkah dalam proses.

- Mendesain proses dengan metode alternatif lain.

- Mengikut sertakan customer \& supplier dalam proses.

- Menggunakan teknologi untuk meningkatkan kinerja prosesnya.

\section{Benchmarking adalah:}

Suatu studi yang dilakukan dengan cara membandingkan terhadap organisasi atau proses sejenis untuk saling mendapatkan hal yang positif.

Tahapan benchmarking adalah:

1. Menentukan Materi Benchmarking.

2. Menentukan Objek Benchmarking.

3. Proses Benchmarking.

4. Analisis Hasil Benchmarking.

5. Kesimpulan Hasil Benchmarking.

DOI: $10.52362 /$ jisicom.v5i1.381

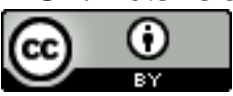

Ciptaan disebarluaskan di bawah Lisensi Creative Commons Atribusi 4.0 Internasional. 
e-ISSN : 2597-3673 (Online) , p-ISSN : 2579-5201 (Printed)

Vol.5 No.1, Juni 2021

Journal of Information System, Informatics and Computing

Website/URL: http://journal.stmikjayakarta.ac.id/index.php/iisicom

Email: jisicom@stmikjayakarta.ac.id , jisicom2017@gmail.com

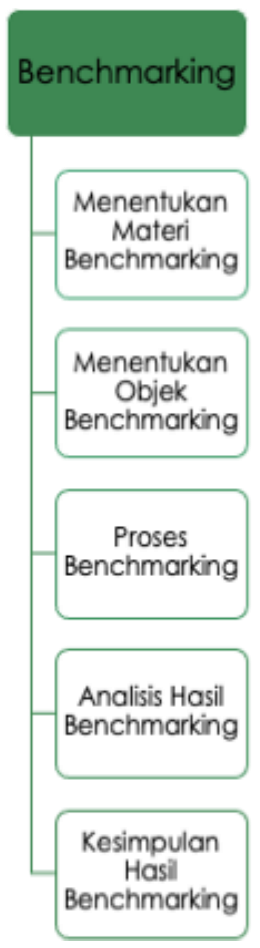

Syarat Benchmarking

Dalam Benchmarking sebaiknya memenuhi persyaratan dibawah ini:

○ Objek Pembanding memiliki tujuan hasil yang sama.

- Objek Pembanding memiliki proses yang sama.

- Objek Pembanding memiliki spesifikasi proses yang sama.

○ Objek Pembanding terukur sehingga memungkinkan untuk dibandingkan.

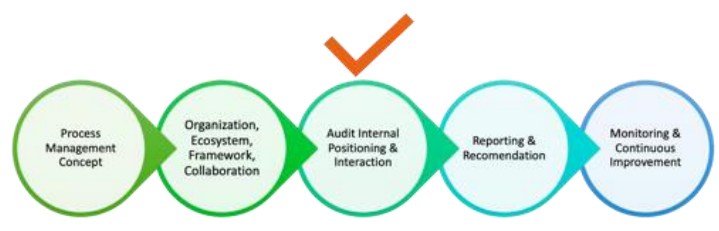

\section{REFERENSI}

[1] P. Harmon and C. Consortium, Handbook on Business Process Management 1, no. March. 2010.

[2] K. Schwab, "The Fourth Industrial Revolution: What It Means and How to Respond," 2017.

[3] P. Diawati, Inovasi sebagai Inti Proses Bisnis : Implementasi pada Keinovasian Wirausaha Industri Kecil. Bandung: Manggu Makmur Tanjung Lestari, 2017.

[4] M. Wibowo, Efisiensi Perusahan melalui Penerapan Manajemen Proses Bisnis. Jakarta: Grasindo, 2014.

[5] J. Tidd and J. Beasant, Managing Innovation:Integrating Technological Market and Organizational Change. United Kingdom: John Wiley and Sons, 2014.

[6] Kamus Besar Bahasa Indonesia, "Definisi Analisis." kbbi.kemdikbud.go.id.

DOI: $10.52362 /$ jisicom.v5i1.381

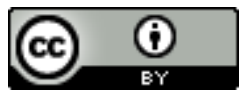

Ciptaan disebarluaskan di bawah Lisensi Creative Commons Atribusi 4.0 Internasional. 
e-ISSN : 2597-3673 (Online), p-ISSN : 2579-5201 (Printed)

Vol.5 No.1, Juni 2021

Journal of Information System, Informatics and Computing

Website/URL: http://journal.stmikjayakarta.ac.id/index.php/jisicom

Email: jisicom@stmikjayakarta.ac.id , jisicom2017@gmail.com

[7] S. Riyanarto, A. H. Fauzan, A. N. Nurlaili, D. Rahmawati, K. R. Sungkono, and Y. A. Effendy, Manajeman Proses Bisnis , Model dan Simulasi (Dasar BPM Certification di www.bpminstitute.org), Edisi Pert. Surabaya: ITS Tekno Sains, 2017.

[8] M. Weske, Business Process Management. 2015.

[9] M. Hammer, "What is Business Process Management," 2015.

[10] J. Vom Brocke, T. Schmiedel, J. Recker, P. Trkman, W. Mertens, and S. Viaene, "Ten principles of good business process management," Bus. Process Manag. J., vol. 20, no. 4, pp. 530-548, 2014, doi: 10.1108/BPMJ06-2013-0074.

[11] M. Von Rosing, H. Von Scheel, and A. W. Scheer, The Complete Business Process Handbook: Body of Knowledge from Process Modeling to BPM, vol. 1. 2014.

[12] R. K. L. Ko, S. S. G. Lee, and E. W. Lee, "Business process management (BPM) standards: A survey," Bus. Process Manag. J., vol. 15, no. 5, pp. 744-791, 2009, doi: 10.1108/14637150910987937.

[13] M. Netjes, H. A. Reijers, and W. M. P. Van Der Aalst, "Supporting the BPM life-cycle with FileNet," CEUR Workshop Proc., vol. 364, pp. 135-146, 2006.

[14] A. Hallerbach, T. Bauer, and M. Reichert, "Managing process variants in the process life cycle," ICEIS 2008 Proc. 10th Int. Conf. Enterp. Inf. Syst., vol. 2 ISAS, pp. 154-161, 2008, doi: 10.5220/0001685001540161.

[15] U. Kannengiesser, "Subsuming the BPM life cycle in an ontological framework of designing," Lect. Notes Bus. Inf. Process., vol. 10 LNBIP, pp. 31-45, 2008, doi: 10.1007/978-3-540-68644-6_3.

[16] M. Zur Muehlen and D. T. Y. Ho, "Risk management in the BPM lifecycle," Lect. Notes Comput. Sci. (including Subser. Lect. Notes Artif. Intell. Lect. Notes Bioinformatics), vol. 3812 LNCS, no. September 2005, pp. 454-466, 2005, doi: 10.1007/11678564_42.

[17] M. Dumas, M. La Rosa, J. Mendling, and H. A. Reijers, "Fundamentals of Business Process Management," 2013.

[18] R. Dijkman, I. Vanderfeesten, and H. a Reijers, "The Road to a Business Process Architecture: An Overview of Approaches and their Use," Architecture, vol. 350, no. July, pp. 1-17, 2011, [Online]. Available: http://cms.ieis.tue.nl/Beta/Files/WorkingPapers/wp_350.pdf.

[19] E. Mahendrawathy, Business Process Management, Konsep dan Implementasi, I, 1st Pub. Yogyakarta: ANDI OFFSET, 2018.

[20] S. Huda, R. Sarno, and T. Ahmad, "Increasing Accuracy of Process-based Fraud Detection Using a Behavior Model,” Int. J. Softw. Eng. Its Appl., pp. 175-188, 2016.

[21] A. J. M. M. Weijters, W. M. . Van der Aalst, and A. K. A. De Medeiros, "Process Mining with the Heuristics Miner-algorithm," Tech. Univ. Eindhoven.

[22] D. Rahmawati, S. Riyanarto, and M. . Yaqin, "Fraud detection on event logs of goods and services procurement business process using Heuristics Miner algorithm," 2016.

[23] M. Dumas, M. La Rosa, J. Mendling, and E. H. A. Reijers, "Fundamentals of Business Process Management," 2018.

DOI: $10.52362 /$ jisicom.v5i1.381

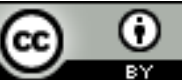

Ciptaan disebarluaskan di bawah Lisensi Creative Commons Atribusi 4.0 Internasional. 